\title{
COLLABORATION OF PARENTS AND TEACHERS - FROM THEORETICAL ASSUMPTIONS TO THEIR PRACTICAL IMPLEMENTATION (THE CASE OF POLISH SCHOOL ABROAD)
}

\author{
Alicja Hruzd-Matuszczyk \\ ORCID iD 0000-0001-7731-7979 \\ M.A., assistant \\ University of Silesia in Katowice \\ Faculty of Ethnology and Education in Cieszyn \\ ul. Bielska 62, 43-400 Cieszyn, Poland \\ alicjahruzd@o2.pl
}

\section{ABSTRACT}

The study is an attempt at characterizing the theoretical assumptions concerning the collaboration of teachers and parents which are implemented in the space of school. What is outlined in the article is the cooperation in the space of the Polish community living abroad in the culturally diversified environment.

The proper functioning of school depends on cooperation between teachers, students and parents. The effectiveness of the cooperation of parents and teachers is determined by many complex factors. In this study, the principles and problems are brought closer that arise from asymmetric positioning of educational subjects (students, teachers and parents), which generates different needs and ideas in mutual cooperation. This is exemplified here by the Polish-language school education system, whose activity reflects the needs and possibilities of the Polish communities in culturally heterogeneous European environments in the creation and functioning of Polish-speaking educational institutions and the involvement of the community gathered around these schools.

Key words: collaboration; parents; teachers; Polish school.

\section{INTRODUCTION}

Effective functioning of school depends on the collaboration of all involved subjects - teachers, learners and parents. This study explores the issues of the collaboration between parents and teachers and of the activities for the school community. Apart from indicating the general regularities concerning the relation between the parent and the teacher, the case of schools with Polish as the teaching language is provided. Their activity illustrates the needs and potentialities of Polish communities in culturally heterogeneous European environments in the field of establishing and functioning of schools with Polish language and the engagement of the communities centred around them.

The article consists of four parts. The first comprises some reflections upon the position of parents in the activity od school. The second provides a closer insight into the cooperation of parents and teachers, in reference to the theoretical assumptions of joint activities. The third part is dedicated to the functioning of a few selected Polish schools abroad and to the activities of their learners' parents. 
The article is completed with a recapitulation and suggestions for solutions in educational practice. The undertaken subject constitutes an introduction to broader studies on the communities associated with the school system with Polish as the teaching language in selected European countries.

\section{SCHOOL - TEACHER - PARENT RELATIONS}

Family and school are the environments which permeate each other in their functioning - creating a network of mutual relations, dependencies and collaboration is necessary for appropriate functioning of both these socialization subjects. The attempts to activate parents, aimed at increasing their participation in school activity and at specifying the significance and forms of cooperation with the school environment, should be comprised in inner regulations of each school (e.g. in its statute) in such a way that the rights and duties of each side could be clearly defined, disseminated and accepted by all interested groups. Some of the tasks assigned to parents at school are fulfilled by joining the collective organs acting at school, such as the school council or parents council.

Parents tend to perceive school through the perspective of their own school experiences and memories. A teacher is associated with the achieved success but also with requirements, bans, their own weaknesses, unpleasant events and failure. Parents (especially those of children who start education) feel as if they were teachers' competitors. So far, they have been the only guardians of their children, now they compare themselves to teachers and defend their own authority. However, as Piotr Kowolik (2005) emphasizes, the majority of parents appreciate the work of educators and their contribution to the good of both the family and school (s. 99).

The teachers' perspective of the relations with parents reveals some critical evaluation of the quality of collaboration between parents and school and that they blame parents for this situation. Teachers stress too little parental engagement in the issues of school and class, in spite of frequent declarations of aid and support. Educators admit that parents join the school life only when their children have various (e.g. learning, related to proper behaviour) difficulties. Teachers' fears also concern parents' critical evaluation of them as well as of the work performed by parents (Kowolik, 2005, s. 99-100).

Most frequently, the cooperation between parents and teachers is of formal nature and the characteristic feature of their activity is the asymmetrical configuration of power. «In teachers' collaboration with parents, no one will act instead of them and substitute them in establishing various contacts, because they are the hosts at school and the choice of contents, forms and methods in the «struggle» for the quality of mutual relations depends on them» (Kowolik, 2005, s. 100).

With concern for the quality and effectiveness of cooperation, it should be assumed that the relations between the teacher and the family ought to be based on a few foundations (Lobocki, 1985, s. 32-35; Kowolik, 2005, s. 103-104):

- the principle of positive motivation - assuming the voluntary character of collaboration and the awareness of the goals of the undertaking and its benefits;

- the principle of partnership - assuming the equivalence of teachers and parents in rights and duties, all decisions undertaken by parents and teachers are worked out together by compromising; 
- the principle of multisided information flow - promoting the activation and use of bi- and multidirectional communication between teachers and parents, as well as within the parental group and among the teaching staff. Such an approach to communication among partners makes it possible to confront the opinions of particular groups on what takes place at school and in the family;

- the principle of impact unity - assuming the fulfilment of common aims in educational work and the awareness concerning the use of methods and forms of work;

- the principle of active and methodical collaboration - the subordination to this rule is diversified for the subjects engaged in education of the young. Teachers are more frequently the active party, which results from their function in the educational process;

- $\quad$ keeping proper balance between common actions for the school and family environments;

- $\quad$ respect for the individuality and dignity of collaborating participants;

- flexible and creative use of the forms of collaboration in daily practice.

The forms of collaboration between school and parents are diversified. The following are most frequently applied by the teacher: joint forms of collaboration of teachers and parents (working meetings - e.g. parental gatherings; social meetings e.g. associated with ceremonies, school events; meetings with specialists - e.g. concerning educational difficulties or the pedagogization of parents); individual forms of collaboration of teachers and parents (pedagogical consultations, home visits, mail contacts, telephone calls); collaboration of teachers and parents in facilitating the work of school (acting within the parental committee, participation in didactic work of school, organizing learners' leisure time and the support for learners in choosing the occupation) (Lobocki, 1985).

\section{COLLABORATION WITH PARENTS - FROM THEORETICAL ASSUMPTIONS TO PRACTICAL IMPLEMENTATION}

The actual inclusion of a parent into the activity for school is not easy. There are many reasons for this inclusion but their causes have different backgrounds. Firstly, this concerns the stereotypical reasoning that when a child is sent to school, it is school (the teaching staff) which takes over the care for and the burden of the child's education. Secondly, there is parental unwillingness to take part in school activities, and thirdly - the lack of skills and unwillingness on the part of teachers.

In expert literature, many causes can be found explaining the lack of or insufficient collaboration between parents and teachers. In Peter Mittler's approach, the causes of failure in this cooperation are the following: 1) insufficient preparation of teachers. No teacher trainings which shape open attitudes towards parents and familiarize teachers with effective methods of collaboration with parents; 2) a psychological and social distance between teachers and parents. Teachers have a lot of difficulty in treating parents as partners; 3) unrealistic requirements and expectations. This concerns both teachers and parents towards each other, as well as each of them towards the child (Florek, 2000, s. 47).

The effectiveness of collaboration of parents and teachers is determined by many factors. One of them is the climate of a particular school and the rules 
of collaboration applied there. It should be already at the stage of teachers' professional preparation that some skills are shaped to minimize the causes of the aforementioned failure. As shown in the team studies conducted by Aleksandra Minczanowska and me (the supervisors of student internships) among teachers of integrated early-school education ${ }^{22}$, during internships - teachers treat the field of cooperation with parents as secondary in rank. During internships, a student mostly fulfils the obligatory integrated classes - 103 (32,8\%), the teacher pays a lot of attention to work and the familiarization of the student with school and class documents - $56(17,83 \%)$. What is typical of work at school are the daily contacts with the teaching staff and school workers (e.g. an educational advisor, a psychologist), which take place also with the participation of young educators (interns) - 47 (14,97\%). Teachers declare students' participation in extracurricular activities (e.g. compensation classes, interest clubs) - 44 (14,01\%) and guardianeducational activities (library and common room classes) - 40 (12,74\%). Among teachers' indications, there is also participation in meetings with parents $24(7,65 \%)$.

Although teachers declare that they consider the platform of cooperation with parents to be an important field of pedagogical work, during the supervision over a pedagogy student (an intern), this area is slightly neglected. The presented research fragment seems to show a tendency present in many Polish schools the focus on didactics and care for the documentation (both important fields), which results in putting aside the elaboration (together with students) of skills concerning collaboration with parents and their commitment to school life.

Therefore, the source of the lack of teachers' preparation for contacts with parents can be sought in insufficient teacher training (e.g. during pedagogical internships), which often does not involve the contact with parents and focuses only on the work with learners. Universities do not prepare - or prepare insufficiently - a young educator for fulfilling the tasks and practical collaboration with parents. Faced with the school reality, a young, inexperienced teacher seems helpless, collecting experience and refinement only later during professional work. Unfortunately, the patterns of work, including the models of collaboration with parents, are not always appropriate.

The quality of collaboration depends both on the teacher and on the parent, though the teacher has the dominating role due to the possibility of coordinating all activities. Yet, teachers should elaborate the tools with which they will be able to combine and use the initiatives or activities of school and parents.

The efficient cooperation of parents and teachers will bring desired results if three conditions are fulfilled: teachers are properly prepared for work with parents, parents are encouraged to collaborate, the fields of cooperation between teachers and parents are specified (Florek, 2000).

In every school, parental activity and cooperation is diversified. Parents can be divided into a few groups representing the level of their engagement in their children's education. In general, the following can be distinguished: committed (active) parents - interested in the quality and effectiveness of work at school, taking active part in school activities, initiating activities associated with the

$22 \quad$ The studies were conducted in 2017 among teachers of integrated early school education. The research involved 110 teachers who had earlier supervised student internships. The studies were aimed at recognizing teachers' opinions concerning their experience of being an internship supervisor and the course of such internships. The presented results are a fragment of broader research into the teachers' environment. The respondents had a possibility to choose more than one answer $(n=314)$. 
functioning of school; additionally, engaged in the functioning and organization of school activity - caring for the development and future of their child's school; uncommitted (passive) parents - whose activity begins and ends at the moment of their child's educational start in a school with Polish as the teaching language (Florek, 2000) ${ }^{23}$.

It seems that that the problem of parental inactiveness, which is raised by teachers, and frequent complaints about school expressed by parents have become a permanent element of the coexistence of school and family. Blaming each other for this state is a road to nowhere. School needs change as regards relations with parents. A change of parental activity means a change in the binding principles of collaboration, in teachers' attitude, school philosophy and the way in which all school activities are organized. Such a change is possible only if people who constitute school start thinking about parents as a group needed or even indispensable for its functioning (Dzierzgowska, 2000, s. 11).

\section{COLLABORATION OF PARENTS AND TEACHERS IN THE ENVIRONMENT OF SCHOOL WITH POLISH AS THE TEACHING LANGUAGE}

What can serve as an interesting case of activities implemented jointly by school and parents are the initiatives undertaken by Polish communities abroad centred around schools with Polish as the teaching language.

The activity of schools conducting education in Polish abroad can take place in different forms:

1) schools belonging to the Centre for the Development of Polish Education Abroad: schools, school complexes and school consultation points at diplomatic representative offices, consular offices and military representative offices;

2) schools of Poles' organizations, social schools - most often, the so called "Saturday schools" run by: non-government organizations, educational organizations of Polish communities abroad, parental associations and Polish parishes;

3) schools in foreign systems of education - schools with Polish as the teaching language, with classes of Polish as the native language, with classes of Polish as a foreign language, Polish sections in international schools in France, Polish sections in European Schools (www-2, www-4, www-5).

A learner living abroad fulfils school duty and educational duty within the local educational system in the residence country. Polish schools offer the possibility of additional education - in the field of the Polish language, history and geography of Poland and other subjects if possible. The educational activity conducted by these schools is aimed at maintaining the bonds with children's or their ancestors' homeland, which consists in learning its language and the knowledge of the native country and its culture.

Attending a Polish school by a child in a foreign country usually takes place for many reasons. Sometimes, the reason is a temporary stay abroad and the

23 In the expert literature, there are works presenting various groups of parents and forms of collaboration at school A simplified classification, which distinguishes committed and uncommitted parents, has been applied here. Other examples of the attitudes and relations (with the teacher) are presented by Anna Florek. 
contact with school ensures educational continuity. Some other reasons can be indicated as well, e.g. making it possible for a child to decide about the place of further education (secondary school or university) in the homeland, maintaining the contact with the native language, building the child's capital - communication in many languages may bring benefits in the nearest future. The families which, due to the performed work (e.g. in management jobs) requiring frequent changes in residence of the whole family, treat the Polish schools abroad as a constant value, provide their children with minimal stabilization in the new, multicultural environments that they need to discover anew from time to time ${ }^{24}$.

Many examples can be provided of various forms of educational activity of schools educating in Polish. What is worth highlighting in reference to the collaboration of parents and teachers is that there are active parental associations in these schools. A very special case is the situation of social schools, which come into being and function as a result of grassroots initiatives of Polish communities and parental associations abroad, who are not indifferent to preserving the Polish national spirit of their descendants. Obviously, it cannot be said that all parents staying abroad are exemplary models and active members of the community in which they live. In each environment, there are committed and uncommitted parents. Both in Poland and abroad, parents excuse their passiveness with trivial reasons - lack of time and being busy with professional and family duties. Regardless of their effort to engage in school activity, parents associated with schools for Polish communities abroad seem full of determination ${ }^{25}$ in implanting the attachment to the native country and language as well as in the cherishing of patriotism to their children. To sum up, although parents' engagement can be evaluated similarly at home and abroad, the motives of parents living abroad are much stronger emotionally, which - among other things - results from yearning for the homeland.

Schools with Polish as the teaching language functioning abroad are of special significance for the education of children and youth as well as for their family life. The diversification of the conducted activities complies with the needs of the Polish community and, in each case, these schools constitute a link which ties the Polish minority in a particular country with their national culture, history and language. Schools are places where Poles living abroad gather, they bring together all generations of immigrants in the need for maintaining the Polish national spirit. School which educates in Polish is a bridge between the Polish culture at home, the world culture and the culture of the residence country. It is at school (and owing to it) where knowledge is passed down and experiences are exchanged among Poles living abroad. In the same way as schools in Poland, schools educating in Polish in foreign states face numerous problems, which in general seem similar but are situated in a different social reality.

$\overline{24}$ Prepared on the basis of the interviews conducted with parents, learners and teachers of selected schools with Polish as the teaching language - School Consultation Points at the Embassies of the Republic of Poland in Vienna, Paris and Prague.

25 This refers to parents' efforts which result from complex circumstances, e.g. there is no obligation to participate in the classes conducted by Polish schools, commuting to schools often consumes a lot of time and effort from parents and children (apart from their other educational and professional duties) School Consultation Points at the Embassies in Prague and Vienna are situated within the city limits but transport (both public and private) takes a lot of time. Frequently, learners who live outside large cities also commute to schools. Even though the classes are held once a week, it is often a challenge to plan and fulfil classes in Polish school. 


\section{RECAPITULATION}

Having analysed the above discussed causes of insufficient collaboration between parents and teachers, it is worth focusing on the activities which might become an impulse for implementing «good practices» at school in the field of collaboration of all the involved parties. Among the suggestions, here called the postulates for educational practice, the following might be indicated:

1. At the stage of preparing teachers for their profession, a future teacher' workshop should be built - comprising collaboration with educational subjects (learners, parents, other teachers, specialists). The postulates in this field also involve shaping an open attitude of future educators to cooperation with parents as well as equipping pedagogy students with the knowledge of methods (and the potentialities of their application!) which they will use at work to implement their tasks. This should be undertaken in the period of theoretical preparation and the acquisition of basic practical skills.

2. Educators ought to be equipped with communication competences, which will allow them to establish proper (and expected by them) relations with parents and will encourage parents to active participation in the activities suggested by teachers.

3. There is a need for specifying clear borderlines which will indicate the requirements and expectations of all educational subjects from each other (teachers, learners, parents) as well as the fields and forms of activities implemented by each party and the activities which will unite the school community in common undertakings.

The awareness that joint activities of parents and teachers for the school community are in fact aimed at the development and good of the child will become a serious argument for active participation of parents in the work of school and in the collaboration with teachers. Teachers need to develop their competences in an unceasing way, to listen to parents' opinions and recognize their needs, to formulate the expectations concerning parental engagement. The sense of the cooperation between school and family, indicated by joint, not imposed activities of parents and teachers might become a start for successful and interdependent collaboration for the good of a child.

The examples of many schools, including Polish schools functioning abroad, show that such good and lasting collaboration of the school and family environments is possible. The commitment to the functioning of these institutions is manifested in the school activity of Polish families, despite (or maybe owing to) the voluntary and supplementary character of education in such schools. The signs of family activeness in creating and functioning of Polish school is particularly visible in social schools, which act owing to the initiative of Polish communities and families, their financing, their care for school infrastructure and their engagement in the organization and work of school. The fact that the Polish family abroad gets linked with the Polish school is a symptom of parental concern for the child's future. This is also associated with the wish to maintain social contacts with Poles and is related to the remembrance concerning the native country. In some cases, the collaboration ends up with enrolling a child to school and taking care of their school presence. However, there are good examples as well - the cases when parents are a part of school and are its flagship in the environment of the residence country. 


\section{REFERENCES}

Dzierzgowska, I. (2000). Rodzice w szkole. Poradnik dla dyrektorów szkót, nauczycieli i rodziców. Warszawa, Polska: CODN.

Florek, A. (2000). Warsztaty «Rodzice i nauczyciele» - płaszczyzny współpracy dla rodziców oraz nauczycieli przedszkoli i szkół podstawowych. In: M. Mendel (Ed.): W poszukiwaniu partnerstwa rodziny, szkoły i gminy. Toruń, Polska: Wyd. Adam Marszałek.

Kowolik, P. (2005). Dialog i współdziałanie szkoły z domem rodzinnym. In: M. Nyczaj-Drag, M. Głażewski (Eds): Wspótprzestrzenie edukacji. Szkoła - rodzina społeczeństwo - kultura. Kraków, Polska: Oficyna Wydawnicza «Impuls».

Łobocki, M. (1985). Współdziałanie nauczycieli i rodziców w procesie roychowania. Warszawa, Polska: Nasza Ksiegarnia.

Podstawa programowa dla uczniów polskich uczacych się za granica. (2010). Warszawa, Polska: MEN. Retrieved from http://www.polska-szkola.pl/file. php/1/ Podstawa_programowa_INTERNET.pdf

Program Rozwoju Oświaty Polskiej za Granica i Oświaty Polonijnej na lata 20092011. Materiat do dyskusji. (2009). Warszawa, Polska: MEN. Retrieved from http://www.polskaszkola.pl/file.php/1/moddata/forum/32/25/plan_dzialan_ projekt.pdf

Ministerstwa Edukacji Narodowej. (2016). Retrieved from http://www.men.gov.pl/ index.php/wspolpraca-miedzynarodowa/ksztalcenie-w-jezyku-polskim

Ośrodek Rozwoju Polskiej Edukacji za Granicą. (2016). Retrieved from http:// www.orpeg.pl/ 